\title{
Genetic Diversity and Population Structure of Plum Accessions from a Romanian Germplasm Collection Assessed by Simple Sequence Repeat (SSR) Markers
}

\author{
Rodica POP ${ }^{1}$, Monica HÂRT, ${ }^{2 *}$, Katalin $\mathrm{SZABO}^{2}$, Maria Z̆̌NESCU ${ }^{2}$, \\ Cristian Radu SISEA ${ }^{1}$, Corina CĂTANĂ ${ }^{1}$, Doru PAMFIL ${ }^{1,2}$ \\ ${ }^{1}$ University of Agricultural Sciences and Veterinary Medicine Cluj-Napoca, Faculty of Horticulture, \\ Department of Horticulture and Landscape, 3-5 Mănăstur Street, Cluj-Napoca, \\ Romania; prodica64@yahoo.com; cristisisea@yahoo.com; corinacatana@usamvcluj.ro;dpamfil@usamvcluj.ro \\ ${ }^{2}$ University of Agricultural Sciences and Veterinary Medicine Cluj-Napoca, Life Sciences Institute, Research Centre for Agricultural \\ Biotechnology affiliated at Romanian Academy, 3-5 Mănăştur Street, Cluj-Napoca, \\ Romania; monica.harta@usamvcluj.ro; ('correspondingauthor); katalin.szabo1980@gmail.com; maria.zanescu@gmail.com
}

\begin{abstract}
In Romania, Prunus genetic resources are held in collections located mainly in research and development institutes or in fruit growing stations. A possible disadvantage of the utilization of these resources for genetic studies and also for breeding programmes is the lack of reliable data for correct identification and characterization of accessions. In this study, 27 plum accessions from Râmnicu-Vâlcea Fruit Research Station, Romania, were assessed using nine SSR markers generating a total of 134 distinct alleles, with an average of 14.89 alleles per locus. Differentiation between the Romanian plum cultivars and international reference cultivars was low, but significant, for all the nine loci $(F s t=0.012 ; \mathrm{P}<0.0001)$. Plum accessions were grouped in two clades, both including old and newly developed Romanian cultivars and also international reference cultivars, according to an UPGMA dendrogram. Bayesian analysis of genetic structure revealed significant admixture among examined accessions while principal coordinate analysis performed on the molecular data illustrated a substantial dispersion of old and newly developed Romanian plum accessions in the three-dimensional PCoA scatter plot. These results could make them attractive for future breeding programs and long-term conservation strategies based on identified genetic dissimilarities.
\end{abstract}

Keywords: Prunus, genetic resources, plum accessions, cluster analysis, Bayesian analysis

\section{Introduction}

The availability of information regarding the molecular characteristics of species of economic interest is important for better use of genetic resources in breeding and conservation strategies (Rao and Hodgkin, 2002; Decroocq et al., 2004, Neumüller, 2011; Igarashi et al., 2016).

Plum is considered an important fruit tree crop of the temperate climate and most of the modern cultivars belong to the hexaploid $(2 n=6 x=48)$ European plum (Prunus domestica L.). This species might have diploid $P$. cerasifera (cherry plum) and tetraploid P. spinosa (sloe) components in the genome structure or can be a descendent of $P$. cerasifera resulting from polyploidization (Botu et al., 2012).

Prunus insititia L. is also a very common hexaploid $(2 n$ $=6 x=48)$ European plum, being classified as a distinct species or subspecies of $P$. domestica (Okie and Hancock,
2008). P. insititia cultivars differs from other European plum cultivars, especially at the fruit traits level, such as size, shape and colour of the fruit that give the plum varieties names as damson, bullace, mirabelle and St. Julien (Halapija Kazija et al., 2014).

Plum cultivation has a historical tradition and economic implication for the South-eastern European countries including Romania. The European plum (Prunus domestica L.) is considered an important indigenous species in the Balkans and thousands of local biotypes were grown here for centuries and being part of the local culture (Botu et al., 2012). In this context, the identification and characterization of the valuable plum genetic resources based on modern methods (SSRs and SNPs markers, HRM analysis) is an important goal for germplasm evaluation in the Balkan countries (Halapija Kazija et al., 2014; Merkouropoulos et al., 2016). 
In Romania, Prunus genetic resources are kept in collections located mainly in research and development institutes or fruit growing stations. During the last years, some of the public holding institutions were reorganized and the number of valuable in situ conserved plum accessions dramatically decreased. Nowadays, most plum orchards in Romania are established by using international cultivars, while the old cultivars can be found only in small orchards or family gardens.

In spite of the current situation, there is an increasing interest of private enterprises to organize their own on farm plum collections and fruit tree nurseries, aiming at multiplying and preserving some valuable autochthonous accessions which are well adapted to the local climatic conditions and produce fruits with high organoleptic qualities (Hârța et al., 2016). On-farm preservation can also boost the local markets development for plum products (Negri, 2003; Sehic et al., 2015).

The classical methods used for the identification of plum cultivars are generally based on morphological and physiological traits (Xuan et al., 2011). However, DNAbased molecular methods represent valuable complementary tools for identifying mislabellings, synonymy and homonymy and for studying the relatedness among cultivars (Decroocq et al., 2004; Horvath et al., 2011).

The most commonly used DNA methods for genetic variation and genetic relationships studies in vegetatively propagated crops are based on SSR (simple sequence repeats) markers (Nybom and Weising, 2010). Microsatellites provide multi-allelic and cost-effective markers for many genera, including Prunus, offering reasonably reproducible results between laboratories (Halapija Kazija et al., 2014).

Disadvantages of these markers include the establishment of common sets of primers used for analysis between labs and also, the methods applied for data analysis (Evans et al., 2009; Sehic et al., 2012) that can differ between laboratories.

The aim of this study was to analyse the genetic diversity and the population structure of the old and newly developed plum accessions maintained ex situ, in the germplasm collection of the Fruit Research Station from Râmnicu-Vâlcea, Romania, and to compare them to four international plum cultivars.

\section{Materials and Methods}

\section{Plant material}

A total of 27 plum accessions were analysed in this study (Table 1): twenty-three representative cultivars for the whole Prunus genetic resources in Romania (old and newly developed cultivars) and four widely cultivated international cultivars that were employed as reference.

Table 1. Plum accessions utilized in this study for SSR analyses and assignment of each genotype to clusters $(K=4)$ defined by Structure (Pritchard $e t$ al., 2000) with probability of membership $Q>0.95$

\begin{tabular}{|c|c|c|c|}
\hline Accession number & Accession name - old $\left({ }^{*}\right)$ and newly developed $\left(^{* *}\right)$ cultivars & Presumed species & Assignment to clusters \\
\hline Romanian accessions & & & $\mathrm{K}=4$ \\
\hline 1 & 'Topval'** & P. domestica & 3 \\
\hline 2 & 'Tuleu gras'** & P. domestica & Admixed \\
\hline 3 & 'Tuleu timpuriu' ** & P. domestica & Admixed \\
\hline 4 & 'Renclod de Caransebeş’ ** & P. domestica & Admixed \\
\hline 5 & 'Pescăruş' ** & P. domestica & Admixed \\
\hline 6 & 'Oltval’ ** & P. domestica & Admixed \\
\hline 7 & 'Pinval' ** & P. insititia & Admixed \\
\hline 8 & 'Tuleu de Sineşti' * & P.domestica & Admixed \\
\hline 9 & 'Voineşti B' * & P. domestica & Admixed \\
\hline 10 & 'Roşior văratec' * & P. domestica & Admixed \\
\hline 11 & ‘Gogoșele Otăşău 5’ * & P. insititia & 1 \\
\hline 12 & 'Mici de Stoiceni' * & P. insititia & Admixed \\
\hline 13 & 'Aurii de Bistrița' * & P. insititia & Admixted \\
\hline 14 & 'Tita'** & P. domestica & Admixted \\
\hline 15 & 'De Boteşti' * & P. insititia & Admixted \\
\hline 16 & 'Boambe de Leordeni'* & P. domestica & Admixted \\
\hline 17 & 'Oltenal' ** & P. domestica & 1 \\
\hline 18 & 'Goldane negre'* & P. insititia & Admixted \\
\hline 19 & 'Roz de Densuş’ * & P. domestica & 3 \\
\hline 20 & 'Grase de Peşteana'* & P. domestica & 4 \\
\hline 21 & 'Roze tari' * & P. domestica & 2 \\
\hline 22 & ‘Gogoşele galbene’ * & P. insititia & Admixted \\
\hline 23 & 'Gogoşele negre' * & P. insititia & Admixted \\
\hline \multicolumn{4}{|c|}{ International reference cultivars } \\
\hline 24 & 'Anna Spath' & P. domestica & 3 \\
\hline 25 & 'Stanley' & P. domestica & Admixted \\
\hline 26 & 'Cacanska Rodna’ & P. domestica & 2 \\
\hline 27 & 'Reine Claude d'Althan' & P. domestica & Admixted \\
\hline
\end{tabular}


92

\section{SSR analysis}

The biological material, represented by young leaves, was collected from a single tree for each of the investigated accessions. DNA was isolated using the CTAB-based method published by Lodhi et al. (1994) and improved by Pop et al. (2003) and Bodea et al. (2016). SSR analysis was carried out with a set of already published nine primer pairs, but with some modifications to the original amplification protocols (Table 2). PCR amplifications were performed in a 96 Well Gradient Palm-Cycler CG 1-96 (Corbett Research). Each reaction mixture (total volume of $12 \mu \mathrm{L}$ ) consisted of DNA template $(20 \mathrm{ng} / \mu \mathrm{L}), 250 \mathrm{nM}$ of each primer (Generi Biotech), $1.5 \mathrm{mM}$ of $\mathrm{MgCl}_{2}, 200 \mu \mathrm{M}$ of dNTPs and 0.5 U Go Taq Polymerase (Promega). The forward primer of each primer pair was labelled with $\mathrm{Cy} 5$ fluorescent dye. Amplicons were checked by electrophoresis on a $1.6 \%$ agarose gel and ethidium bromide staining. Diluted PCR products were mixed with sample loading solution ( $37 \mu \mathrm{L}$ for each sample), followed by the addition of Genomelab DNA Standard Kit-400 $(0.3 \mu \mathrm{L})$ and separated using a CEQ 8800 capillary DNA analysis system (Beckman Coulter). Allele sizes were determined for each SSR locus using the Beckman CEQ fragment analysis software. PCR amplifications were repeated twice to ensure the reproducibility of results.

\section{Data analysis}

In order to perform the statistical analysis of the molecular data, the plum accessions were divided into two groups: Romanian cultivars and international reference cultivars. Population genetics software SPAGeDI 1.5 (Hardy and Vekemans, 2002) was used to calculate gene diversity (Nei, 1978), allele frequencies and F statistics (Weir and Cockerham, 1984) for each designated group. Analysis of molecular variance (AMOVA) was performed using GenoType software (Meirmans and van Tienderen, 2004) with 1000 permutations, based on stepwise mutation model.

The cluster analysis was conducted based on SSR allelic data. Amplification products for each analysed accession were scored as "present" or "absent" and transferred to a binary matrix. The genetic distances were calculated using Nei72 similarity coefficient and a UPGMA dendrogram was constructed based on a symmetric dissimilarity matrix using the SHAN module in NTSYS pc 2.1 (Rohlf, 2000). The COPH and MXCOP modules of NTSYS pc 2.1 were used to check the goodness-of-fit between the cluster analysis and dissimilarity matrix. The principal coordinate analysis (PCoA) of the original binary data matrix and based on Jaccard coefficient was performed using the DCENTER and EIGEN modules of NTSYS pc 2.1, in order to examine the relationships and differentiations between plum accessions.

A Bayesian model-based clustering method, employing STRUCTURE version 2.3.4 (Pritchard et al., 2000), was applied to analyse the population structure. As plum is a hexaploid species $(2 n=6 \mathrm{x})$, each analysed accession can have up to six alleles per locus. For individuals with less than six allelic variants, absent allele(s) was assigned as missing data (-9). Ten independent replicates run for each number of clusters ( $\mathrm{K}$ value ranging from 1 to 10 ) were conducted using the admixture model and assuming that sampled accessions were from unknown origin. Each run involved a burning period of 100.000 iterations and a post burning simulation length of 100.000 (Hubisz et al., 2009). The Structure Harvester ver. 0.6.1, a web-based program (Earl Dent and von Holdt, 2012), which implemented the Evanno method (Evanno et al., 2005), was applied to estimate the most probable $K$ value for the analysed data. After the $K$ value was determined, the run with the maximum likelihood was used to subdivide the accessions into specific clusters (Vigouroux et al., 2008) based on proportional membership coefficient $\mathrm{Q}$. Accessions with $\mathrm{Q}$ $>0.95$ were considered to constitute the genetically homogenous subgroups. Those accessions with the membership probabilities less than 0.95 value were included in the admixed group.

Table 2. Characteristics of the nine SSR primer pairs (F-forward; R-reverse) and PCR conditions used in the assessment of plum accessions

\begin{tabular}{|c|c|c|c|c|c|}
\hline Locus name & Species of origin & Primer pairs sequences $\left(5^{\prime}-3^{\prime}\right)$ & Reference & $\begin{array}{l}\text { Annealing temp. } \\
\left({ }^{\circ} \mathrm{C}\right)\end{array}$ & $\mathrm{N}^{\mathrm{o}}$ of cycles \\
\hline UDP96-01 & Peach & $\begin{array}{l}\text { F:AGTTTGATTTTCTGATGCATCC } \\
\text { R:TGCCATAAGGACCGGTATGT }\end{array}$ & $\begin{array}{l}\text { Cipriani et al. } \\
\text { (1999) }\end{array}$ & 65 & 30 \\
\hline UDP96-10 & Peach & $\begin{array}{l}\text { F:CCCATGTGTGTCCACATCTC } \\
\text { R:TTGATGATTCCATGCGTCTC }\end{array}$ & $\begin{array}{l}\text { Cipriani et al. } \\
\text { (1999) }\end{array}$ & 65 & 30 \\
\hline UDP96-19 & Peach & $\begin{array}{c}\text { F:TTGGTCATGAGCTAAGAAAACA } \\
\text { R:TAGTGGCACAGAGCAACACC }\end{array}$ & $\begin{array}{l}\text { Cipriani et al. } \\
\text { (1999) }\end{array}$ & 55 & 35 \\
\hline UDAp-404 & Apricot & $\begin{array}{l}\text { F:CATGAACAGGGTCAAAAGCA } \\
\text { R:TATATCCTTACGCGGCCTCA }\end{array}$ & $\begin{array}{l}\text { Messina et al. } \\
\quad(2004)\end{array}$ & 64 & 30 \\
\hline Pchgms 1 & Peach & $\begin{array}{l}\text { F:GGGTAAATATGCCCATTGTGCAATC } \\
\text { R:GGATCATTGAACTACGTCAATCCTC }\end{array}$ & $\begin{array}{l}\text { Sosinski et al. } \\
\qquad(2000)\end{array}$ & 65 & 30 \\
\hline $\mathrm{UCDCH}-13$ & Cherry & $\begin{array}{c}\text { F:ACCCGCTTACTCAGCTGAAC } \\
\text { R:TTAGCACTAAGCCTTTGCTGC }\end{array}$ & Struss et al. (2003) & 67 & 30 \\
\hline $\mathrm{UCDCH}-21$ & Cherry & $\begin{array}{l}\text { F:TTGTTGACCATCGAATATGAAG } \\
\text { R: GAAGGTACATGGCGTGCC }\end{array}$ & Struss et al. (2003) & 60 & 45 \\
\hline ВРРСТ-014 & Japanese plum & $\begin{array}{l}\text { F: TTGTCTGCCTCTCATCTTAACC } \\
\text { R: CATCGCAGAGAACTGAGAGC }\end{array}$ & $\begin{array}{l}\text { Dirlewanger et al. } \\
\qquad(2002)\end{array}$ & 58 & 40 \\
\hline ВРРСТ-039 & Japanese plum & $\begin{array}{l}\text { F:ATTACGTACCCTAAAGCTTCTGC } \\
\text { R:GATGTCATGAAGATTGGAGAGG }\end{array}$ & $\begin{array}{l}\text { Dirlewanger } \mathrm{et} \text { al. } \\
\qquad(2002)\end{array}$ & 58 & 40 \\
\hline
\end{tabular}




\section{Results and Discussion}

\section{SSR polymorphism and genetic diversity}

The results showed that SSR markers can be effectively used for genetic characterization of Prunus accessions. In this study, nine primer pairs amplified 134 distinct alleles with an average of 14.89 alleles per locus (Table 3). A previous SSR analysis (Öz et al. 2013) shows that in East Anatolian plum accessions 4 and 6 alleles were detected at the loci UCD-CH13 and UDP96-019. Furthermore, we found that these two loci show a higher number of alleles (10 and 11 alleles, respectively) in the Romanian plum accessions. When considering the separate groups analyzed in this study (i.e., Romanian versus international reference cultivars), the largest average number of alleles per locus (14.11) was identified for Romanian accessions, while the value was much lower (7.67) for the international reference cultivars. This difference in the average number of alleles per locus can probably be explained by the lower number of analysed plum cultivars in the reference group. The highest number (31) of different alleles was detected for the
BPPCT-014 locus, while the lowest (7) was recorded for the UDP96-01 locus.

High gene diversity was detected among Romanian accessions (0.87), but also among international reference cultivars (0.86). The average values obtained for this parameter (Table 3), expressed as expected heterozygosity, were slightly lower than the ones reported by Halapija Kazija et al. (2014) (0.90 and 0.89, respectively), recorded as a result of a SSR comparative analysis of Croatian and international plum cultivars where other 9 different primer pairs were used.

\section{Genetic relationships and dissimilarities}

UPGMA cluster analysis grouped all the 27 plum accessions into a dendrogram with two main clades (marked $A$ and $B$ ), both including old and new developed Romanian cultivars and also international reference cultivars (Fig. 1). The cophenetic correlation ( 0.89 value of the $r$ coefficient) indicates a good fit between the original similarity matrix and the built dendrogram. The cultivars clustered into four main groups, at Nei72's similarity coefficient of 0.451 (Fig. 1).

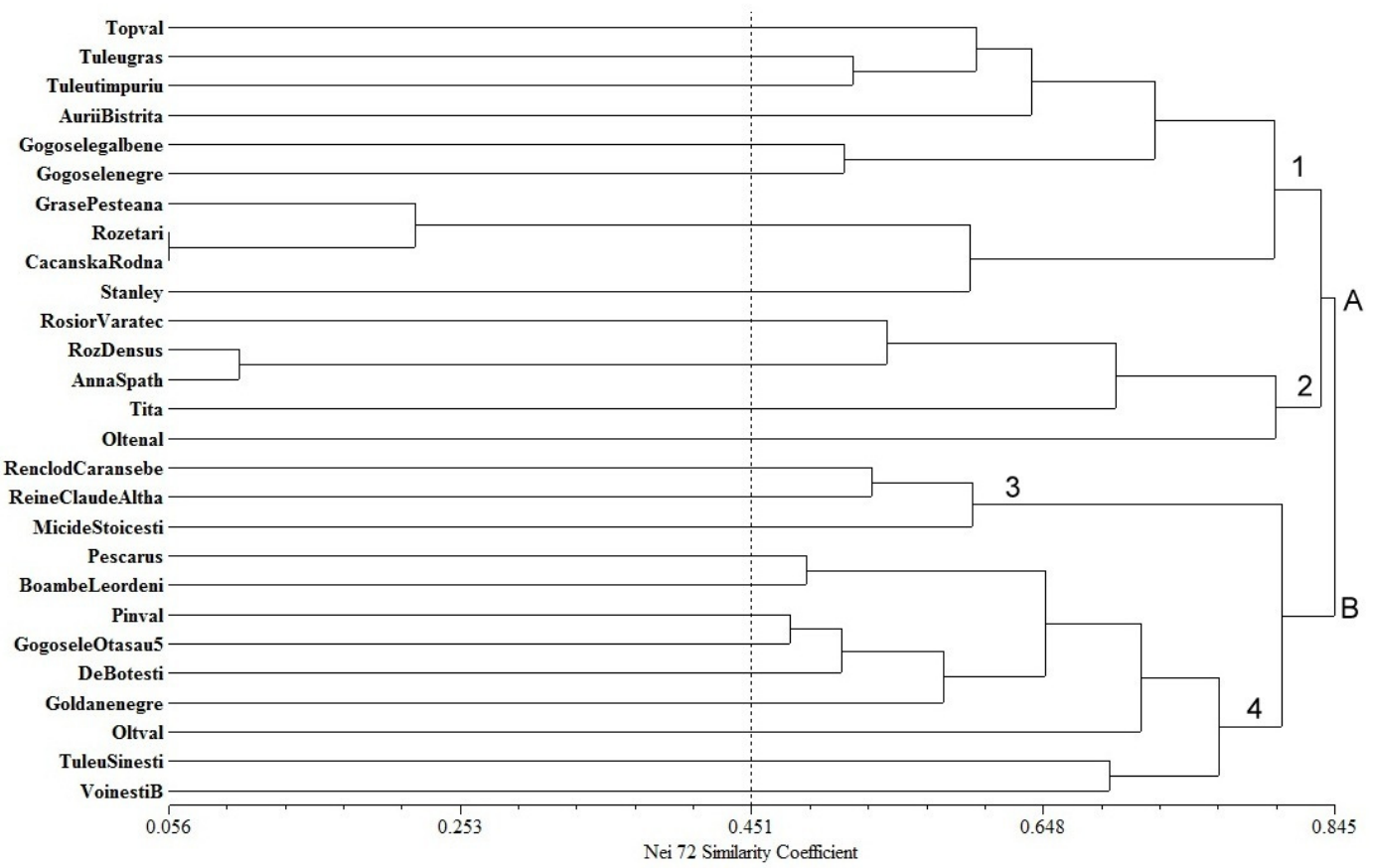

Fig. 1. Dendrogram of the 27 plum accessions derived from UPGMA cluster analysis based on Nei72's similarity coefficient

Table 3. Allele size range (bp), number of alleles per locus and gene diversity (Nei, 1978) for the analysed Romanian plum cultivars ( $\mathrm{N}=23)$ and international cultivars $(\mathrm{N}=4)$, based on 9 SSR loci

\begin{tabular}{|c|c|c|c|c|c|c|c|}
\hline \multirow{2}{*}{ Locus code } & \multirow{2}{*}{$\begin{array}{c}\text { Size range } \\
\text { (bp) }\end{array}$} & \multicolumn{2}{|c|}{ Romanian cultivars $(N=23)$} & \multicolumn{2}{|c|}{ International reference cultivars $(N=4)$} & \multicolumn{2}{|c|}{ All analysed cultivars $(N=27)$} \\
\hline & & $\mathrm{N}^{\circ}$ of alleles & Gene diversity & $\mathrm{N}^{\circ}$ of alleles & Gene diversity & $\mathrm{N}^{\circ}$ of alleles & Gene diversity \\
\hline UDP96-01 & $97 / 111$ & 7 & 0.79 & 6 & 0.79 & 7 & 0.78 \\
\hline UDP96-10 & $65 / 101$ & 12 & 0.87 & 10 & 0.87 & 13 & 0.88 \\
\hline UDP96-19 & $153 / 180$ & 11 & 0.84 & 6 & 0.83 & 11 & 0.84 \\
\hline UDAp-404 & $159 / 175$ & 9 & 0.88 & 6 & 0.86 & 10 & 0.87 \\
\hline Pchgms 1 & $166 / 184$ & 9 & 0.85 & 6 & 0.83 & 9 & 0.85 \\
\hline UCDCH-13 & $125 / 149$ & 10 & 0.84 & 6 & 0.80 & 10 & 0.83 \\
\hline UCDCH-21 & $100 / 122$ & 12 & 0.88 & 8 & 0.88 & 12 & 0.88 \\
\hline ВРРСТ-014 & $171 / 271$ & 31 & 0.92 & 10 & 0.92 & 35 & 0.92 \\
\hline ВРРСТ-039 & $113 / 189$ & 26 & 0.94 & 11 & 0.94 & 27 & 0.94 \\
\hline Mean & & 14.11 & 0.87 & 7.67 & 0.86 & 14.89 & 0.87 \\
\hline
\end{tabular}


94

The first cluster consisted of two subgroups: a larger one, in which eight Romanian cultivars were grouped, and a smaller one including both Romanian accessions ('Grase Peșteana' and 'Roze tari') and international cultivars ('Cacanska Rodna' and 'Stanley'). The close disposition of 'Cacanska Rodna' and 'Stanley' reference cultivars was very similar to that reported by Sehic et al. (2015). It is worth mentioning that the local Romanian 'Roze tari' cultivar appears to be a duplicate of the 'Cacanska Rodna' international cultivar, because in the dendrogram constructed on our SSR data, the two cultivars were grouped on the same line. The possible explanation for this result is the lack of data referring to origin of this Romanian local variety and to the historical conditions in which the plum genetic material was exchanged between Romania and neighbouring countries.

Regarding the second cluster, it is interesting to note that 'Roz Densuş, a local Transylvanian cultivar, clustered together with 'Anna Späth', a Hungarian plum cultivar, of unknown origin, which was discovered by Späth, in 1874. It is therefore possible that, because of the historical conditions of that period, the two old cultivars have a common ancestor. The third and fourth clusters contain both old varieties and newly bred ones, some of them having a complex genetic structure that resulted from conventional breeding activities (Fig. 1). Overall, there was no notable separation of Romanian cultivars from the reference ones and this is probably due to the complex relationships among the polyploid plums, conclusion also reported by Halapija Kazija et al. (2014). The F statistics data obtained using SPAGeDI 1.5 (Hardy and Vekemans, 2002) showed a low differentiation, but significant, for all the nine loci $\left(F_{s t}\right.$ value $0.012 ; \mathrm{P}<0.0001$ ). Analysis of molecular variance (AMOVA) also confirmed that the differences among the analysed groups $(1.7 \% ; \mathrm{P}<0.01)$ account for a small, but significant, part of the total diversity. Comparable results have previously been reported by Sehic et al. (2015) in a study referring to ex situ and on-farm preserved Norwegian cultivars and international plum accessions.

Principal coordinate analysis (PCoA) based on Jaccard dissimilarity coefficient confirmed the number of clusters revealed by UPGMA cluster analysis (Fig. 2).

Substantial dispersion of old and newly developed Romanian plum accessions in the PCoA plot suggests a high level of diversity, which can make them attractive for future breeding programs and long-term conservation strategies.

\section{Genetic structure}

Bayesian analysis of the 27 accessions was used to subdivide the plum accessions into specific clusters. Subsequent $\Delta K$ analyses (Evanno et al., 2005) revealed a maximum value for $\mathrm{K}=4$, as can be seen in Fig. 3 .
The results obtained in the run with the maximum likelihood revealed that the overall proportion of membership of the sample was 0.24 , for clusters 1 and 4 , and 0.26 , for clusters 2 and 3 .

The bar plot of the results from the Bayesian analysis are presented in Fig. 4. It can be observed that most of the accessions were distributed in multiple clusters, based on $\mathrm{Q}$ value, results which are in agreement with similar results reported by Xuan et al. (2011), based on plum SSR analysis.

Therefore, the number of STRUCTURE clusters (4) was equal with the number of subgroups generated in the UPGMA cluster analysis, showing also a high proportion of the admixed plum individuals.

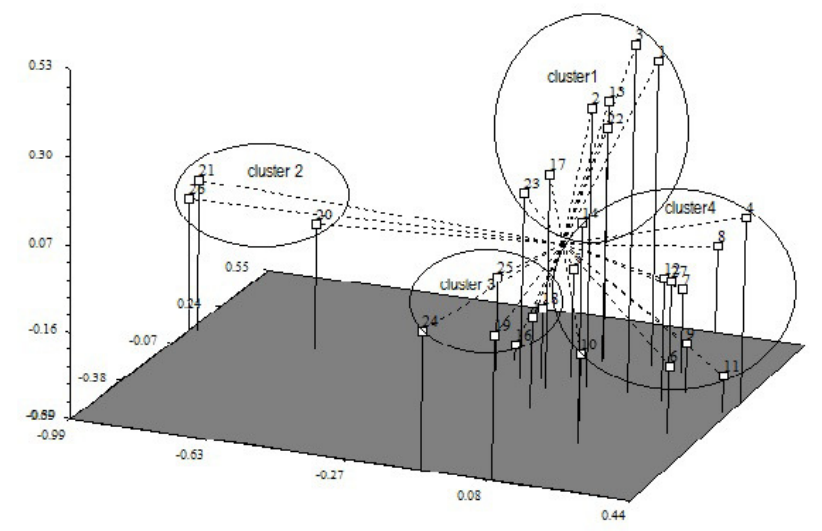

Fig. 2. PCoA plot based on Jaccard coefficient for the 27 analysed plum accessions (the accession number codes on the plot refer to Table 1)

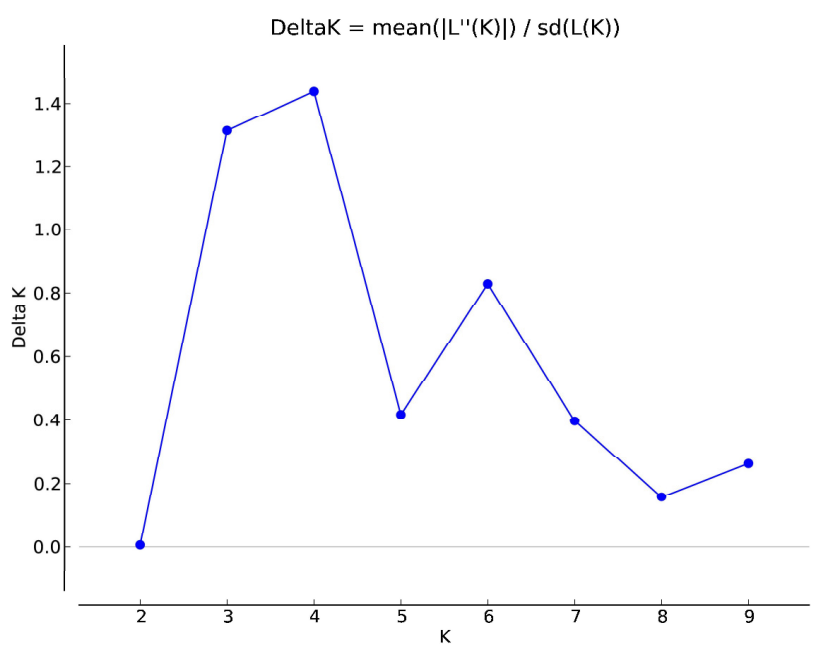

Fig. 3. Estimation of the most probable $K$ value for the 27 analysed plum cultivars, based on the Evano (2005) method

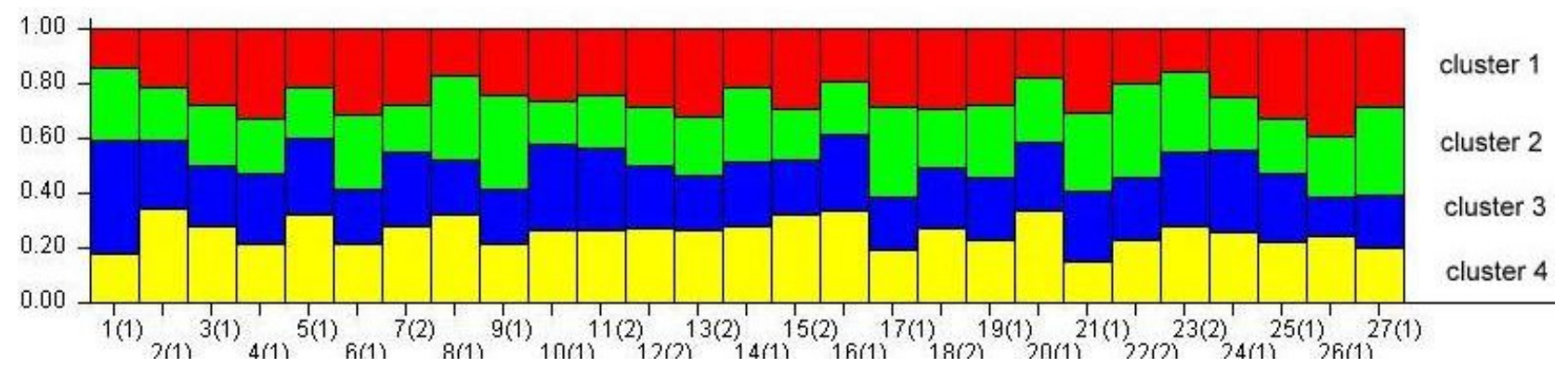

Fig. 4. Bar plot of the results from the Bayesian analysis $(\mathrm{K}=4)$ on plum accessions. On the horizontal axis: (1), (2) indicate accessions from Prunus domestica and P. insititia respectively 


\section{Conclusions}

The high gene diversity detected with the set of the primer pairs used in this study and the substantial dispersion of old and new developed Romanian plum accessions in the PCoA plot make these accessions attractive for future breeding programs and long-term conservation strategies. UPGMA cluster dendrogram revealed the possible presence of one duplicate between the local Romanian and international plum groups and may lead to other analyses in the future. The Bayesian analysis of genetic structure indicates that the identified clusters have a high level of admixture probably due to the complex relationships generated by the level of ploidy and also by the historical context in which the plum genetic material was exchanged between Romania and the neighbouring countries.

\section{Acknowledgements}

This paper was supported by the PN-II-PT-PCCA2013-2014, project no. 168/2014 GERMPLUM. The authors sincerely acknowledge Fruit Research Station from Râmnicu-Vâlcea, Romania, for providing the plant material used for SSR analyses. The authors thank the anonymous reviewers who have contributed to improving the scientific quality of this manuscript.

\section{References}

Bodea M, Pamfil D, Pop R, Sisea RC (2016). DNA isolation from desiccated leaf material from plum tree (Prumus domestica $\mathrm{L}$ ) molecular analysis. Bulletin UASVM Horticulture2016(1):1-2.

Botu I, Botu M, Papachatzis A, Cosmulescu S, Preda S (2012). Evolution of plum culture; constrains and perspectives. Acta Horticulture 968:19-24.

Cipriani G, Lot G, Huang WG, Marrazzo MT, Peterlunger E., Testolin R (1999). AC/GT and AG/CT microsatellite repeats in peach [Prunus persica (L) Batsch]: isolation, characterization and cross-species amplification in Prunus. Theoretical and Applied Genetics 99:65-72.

Decroocq V, Hagen LS, Fave MG, Eyquard JP, Pieronnet A (2004). Microsatellite markers in the hexaploid Prunus domestica species and parentage lineage of three European plum cultivars using nuclear and chloroplast simple-sequence repeats. Molecular Breeding 13:135-142.

Dirlewanger E, Cosson P, Tavud M, Aranzana MJ, Poizat C, Zanetto A, Arús P, Laigret F (2002). Development of microsatellite markers in peach [Prunus persica (L.) Batsch] and their use in genetic diversity analysis in peach and sweet cherry (Prunus avium L). Theoretical and Applied Genetics 105:127-138.

Earl Dent A, von Holdt BM (2012). STRUCTURE HARVESTER: a website and program for visualizing STRUCTURE output and implementing the Evanno method. Conservation Genetics Resources 4(2):359-361.

Evanno G, Regnaut S, Goudet J (2005). Detecting the number of clusters of individuals using the software STRUCTURE: a simulation study. MolecularEcology 14:2611-2620.

Evans KM, Fernandez-Fernandez F, Govan C (2009). Harmonising fingerprinting protocols to allow comparisons between germplasm collections-Pyrus. Acta Horticulturae 814:103-106.
Halapija Kazija D, Jelačić T, VujevićP, Milinović B, ČičekD, Biško A,... Gaši F (2014). Plum germplasm in Croatia and neighbouring countries assessed by microsatellites and DUS descriptors. Tree Genetics \& Genomes 10:761-778.

Hardy OJ, Vekemans X (2002).SPAGeDi: a versatile computer program to analyse spatial genetic structure at the individual or population levels. Molecular Ecology Notes 2:618-620.

Hârța M, Sisea CR, Pop R, Szabo K, Zănescu M, Clapa D, ... Pamfil D (2016). The Current Status of Germplum Database: a Tool for Characterization of Plum Genetic Resources in Romania. Bulletin UASVMHorticulture 73(2):240-241.

Horvath A, Balsemin E, Barbot JC, Christmann H, Manzano G, Reynet P, Laigret F, Mariette S (2011). Phenotypic variability and genetic structure in plum (Prunus domestica L.), cherry plum (P. cerasifera Ehrh.) and sloe (P.spinosa L). Scientia Horticulturae 129:283-293.

Hubisz MJ, Falush D, Stephens M, Pritchard JK (2009). Inferring weak population structure with the assistance of sample group information. Molecular Ecology Resources 9(5):1322-1332.

Igarashi M, Hatsuyama Y, Harada T, Fukasawa-Akada T (2016). Biotechnology and apple breedingin Japan. BreedingSciences 66(1):1833.

Lodhi MA, Ye GN, Weeden NF, Reisch BI (1994). A simple and efficient method for DNA extraction from grapevine cultivars Vitis species. Plant Molecular Biology Reporter 12(1): 6-13.

Meirmans PG, Van Tienderen PH (2004). GENOTYPE and GENODIVE: two programs for the analysis of genetic diversity of asexual organisms. Molecular Ecology Notes 4:792-794.

Merkouropoulos G, GanopoulosJ, Tsaftaris A, Papadopoulos I, Drogoudi P (2016). Combination of high resolution melting (HRM) analysis and SSR molecular markers speeds up plum genotyping: case study genotyping the Greek plum GeneBank collection. Plant Genetic Resources 15(4):366-375.

Messina R, Lain O, Marrazzo MT, Cipriani G, Testolin R( 2004). New set of microsatellite loci isolated in apricot. Molecular Ecology Notes 4:432434.

Negri V (2003).Landraces in central Italy: where and why they are conserved and perspectives for their on-farm conservation. Genetic Resources and Crop Evolution 50:871-885.

Nei M (1978). Estimation of average heterozygosity and genetic distance from a small number of individuals. Genetics 89:583-590.

Neumüller M (2011). Fundamental and applied aspects of plum (Prunus domestica) breeding. In: Global Science Books. Fruit, Vegetable and Cereal Science and Biotechnology 5:139-156.

Nybom H, Weising K (2010). DNA-based identification of clonally propagated cultivars. In: Janick J (Ed). Plant Breeding Reviews. WileyBlackwell 34:221-295.

Okie WR, Hancock JF (2008). Plums. In: Hancock JF (Ed). Temperate Fruit Crop Breeding: Germplasm to Genomic. Springer, New York pp 337-358.

Öz MH, Vurgun H, Bakir M, Büyük I, Yüksel C, Ünlü HM,... Ergül A (2013).Molecular analysis of East Anatolian traditional plum and cherry accessions using SSR markers. Genetics and Molecular Research 12(4):5310-5320. 
96

Pop R, Ardelean M, Pamfil D, Gaboreanu IM (2003). The efficiency of different DNA isolation and purification in ten cultivars of Vitis vinifera. Bulletin USAMVBiotechnology 59:259-261.

Pritchard JK, Stephens M, Donnelly P (2000). Inference of population structure using multilocus genotype data. Genetics 155:945-959.

Rao VR, Hodgkin T (2002). Genetic diversity and conservation and utilization of plant genetic resources. Plant Cell Tissue and Organ Culture 68:1-19.

RohlfFJ (2000). NTSYS-pc: numerical taxonomy and multivariate analysis system. Exeter Publ, Setauket, NY.

Sehic J, Garkava-Gustavsson L, Fernandez-Fernandez F, Nybom H (2012). Genetic diversity in a collection of European pear (Pyrus communis) cultivars determined with SSR markers chosen by ECPGR Scientia Horticulturae 145:39-45.

Sehic J, Nybom H, Hjeltnes SH, Gaši F (2015). Genetic diversity and structure of Nordic plum germplasm preserved ex situ and on-farm. Scientia Horticulturae 190:195-202.
Sosinski B, Gannavarapu M, Hager LD, Beck LE, King GJ, Rajapakse S, ... Abbott AG (2000). Characterization of microsatellite markers in peach (Prunus persica L. Batsch). Theoretical and Applied Genetics 101:421428.

Struss D, Ahmad R, Southwick SM, Boritzki M (2003). Analysis of sweet cherry (Prunus avium L.) cultivars using SSR and AFLP markers. Journal of the American Society for Horticultural Sciences 128:904 909.

Vigouroux Y, Glaubitz JC, Matsuoka Y, Goodman MM, Sanchez GJ, Doebley J (2008). Population structure and genetic diversity of New World maize races assessed by DNA microsatellites. American Journal ofBotany 95:1240-1253.

Weir BS, Cockerham CC (1984). Estimating F-statistics for the analysis of population structure. Evolution 38:1358-1370.

Xuan H, Ding Y, Spann D, Moller O, Buchele M, Neumuller M (2011). Microsatellite markers (SSR) as a tool to assist in identification of European plum (Prunus domestica L.). Acta Horticulture 918:689-692. 